Acta Protozool. (2019) 58: 115-124

www.ejournals.eu/Acta-Protozoologica

doi:10.4467/16890027AP.19.012.11421

PROTOZOOLOGICA

\title{
Molecular Phylogeny of the Sand-dwelling Dinoflagellate Planodinium striatum and Chrysodinium gen. nov. for Plagiodinium ballux (Dinophyceae)
}

LSID urn:1sid:zoobank.org:pub:EA0D4B4A-6749-4DAE-B991-D26FA554FA5E

\author{
Fernando GÓMEZ ${ }^{\mathrm{a}, \mathrm{c}}$, Yasuhide NAKAMURA ${ }^{\mathrm{b}}$, Luis F. ARTIGAS ${ }^{\mathrm{c}}$ \\ ${ }^{a}$ Carmen Campos Panisse 3, E-11500 Puerto de Santa María, Spain \\ ${ }^{\mathrm{b}}$ Department of Botany, National Museum of Nature and Science, Amakubo 4-1-1, Tsukuba, Ibaraki-ken, 305-0005 Japan \\ ' Université du Littoral Côte d'Opale, Université de Lille, CNRS UMR 8187 LOG, Laboratoire d'Océanologie et de Géosciences, \\ Maison de la Recherche en Environnement Naturel, 32 av. Foch, 62930 Wimereux, France
}

\begin{abstract}
The molecular phylogeny of the sand-dwelling dinoflagellate Planodinium striatum was investigated from isolates collected in the NE English Channel. In the SSU rRNA gene phylogeny, the sequences of Planodinium clustered with the type species of Plagiodinium, $P$. belizeanum, and more distantly related to Plagiodinium ballux. Although the SSU rRNA gene sequences of Planodinium showed a high percentage of identity ( $96 \%$ ) with partial sequences of species of Podolampas ( 1200 base pairs), the SSU rRNA gene phylogenies did not show a relationship with the clade of the Podolampadaceae (Podolampas, Blepharocysta, Roscoffia), neither with the sequences of the sanddwelling genus Cabra. The SSU rRNA gene sequences of Plagiodinium belizeanum and P. ballux showed a low percentage of identity (96\%) clustering in separate clades in the SSU rRNA gene phylogeny with Planodinium. The morphology of $P$. ballux and its generic type differed in the plate arrangement and the morphology of the cingulum, amongst other features. Based on the morphological and molecular differences, we propose the new genus Chrysodinium gen. nov. for P. ballux, with the re-interpreted thecal plate formula Po 3' 1" $7 \mathrm{c} 2 \mathrm{~s} 5$,'” 1 ','.
\end{abstract}

Keywords: benthic Dinophyta, microphytobenthos, molecular phylogeny, new genus, Podolampadaceae, psammophilic Dinophyceae.

\section{INTRODUCTION}

Numerous sand-dwelling dinoflagellates have been reported from the English Channel and the North Sea where macrotidal regime results in important emersion periods affecting wide sandy beaches. During ebb tide, the exposed substratum becomes green or golden brown in color in irregular areas of the inter-

Address for correspondence: Fernando Gómez, Carmen Campos Panisse 3, E-11500 Puerto de Santa María, Spain; Email: fernando. gomez@fitoplancton.com tidal sand-flats (Gómez et al. 2011, Gómez and Artigas 2014). From the sandy beaches of the British coasts, Saunders and Dodge (1984) described the new genus and species Planodinium striatum as a laterally flattened heterotrophic dinoflagellate with a small epitheca and horizontal cingulum. Saunders and Dodge (1984) considered Thecadinium petasatum, reported from the coasts of British Columbia by Baillie (1971), as an earlier record of $P$. striatum. Hoppenrath et al. (2014) compiled records of $P$. striatum from the North, Mediterranean and Japan Seas, that suggest a wide distribution in cold and temperate waters. 
Saunders and Dodge (1984) described Planodinium striatum with the plate formula 3'7" 6c 3"', 1 ,'”. They reported: 'there are some similarities between this organism and Balech's (1956) Roscoffia capitata'. The hypotheca of the sand-dwelling genus Roscoffia shows five postcingular plates (5'”) and a single antapical plate (1 '”') (Horiguchi and Kubo 1997, Hoppenrath and Elbrächter 1998). In the original description, Saunders and Dodge (1984) omitted two narrow longitudinal plates (two postcingular plates) that surrounded the sulcus, which sutures can be easily mistaken for the longitudinal ridges in the hypothecal plates. Hoppenrath et al. (2014) redefined the plate formula of $P$. striatum as 3' 1a 8" 7?c 5"' 1",' being closer to Roscoffia. This hypothecal tabulation ( 5 '” 1 "'”) is also found in pelagic dinoflagellates such as Archaeosphaerodiniopsis (Carbonell-Moore 2017) and the Podolampadaceae (Podolampas, Blepharocysta and allied genera) (Carbonell-Moore 2004). Saldarriaga et al. (2003) suggested affinities of Roscoffia with the podolampadaceans, confirmed with the first molecular data of Podolampas and Blepharocysta (Gómez et al. 2010). The hypothecal plate formulae 5"' 1 "', have been also reported for other sand-dwelling genera such as Cabra, Madanidinium, Pileidinium, Plagiodinium, Rhinodinium or Sabulodinium (see a review in the tabulation in Yamaguchi et al. 2018). Wakeman et al. (2018) reported the first molecular data of the type species of Plagiodinium, $P$. belizeanum, and they did not find support for affinities with Roscoffia in the SSU rRNA gene phylogeny. Yamada et al. (2018) described a new species of Plagiodinium, $P$. ballux, and they provided other rRNA gene sequences identified as Plagiodinium belizeanum. The three SSU rRNA gene sequences of Plagiodinium did not show a phylogenetic relationship to Roscoffia (Yamada et al. 2018). In the original description of the genus Cabra, Murray and Patterson (2004) suggested a phylogenetic relationship with the podolampadaceans. Yamaguchi et al. (2018) reported the first molecular data of the type species of the genus Cabra, C. matta, which sequences clustered with Roscoffia, Podolampas and Blepharocysta. In contrast to the previous phylogenies, Yamaguchi et al. (2018) reported Plagiodinium belizeanum as the most basal lineage of the clade of the podolampadaceans. The relationships between Plagiodinium and the podolampadaceans (Roscoffia, Podolampas, Blepharocysta) varied among these three publications with common co-authors. In the present study, we provide the first molecular data of the type species of the genus Planodinium.

\section{MATERIALS AND METHODS}

\section{Source, isolation and microscopy observations}

This study was undertaken in the soft sandy sediments of the shore of Wimereux, France (50 46' $12^{\circ}$ ' N, $1^{\circ} 36^{\prime} 42^{\prime \prime}$ E) in June 2012. The upper centimeter of sand smaller pools and moist sands with a faint brownish discoloration was collected with a spoon and deposited into a bottle. There, the sand was rinsed with seawater and stirred vigorously, and the suspension settled in a composite settling chamber. The settled material was examined with an inverted microscope (Eclipse TE2000-S, Nikon, Tokyo, Japan) and photographed with a digital camera (Digital Sight DS-2M, Nikon, Tokyo, Japan). For scanning electron microscopy, aliquots of the agitated sand samples were fixed with glutaraldehyde (5\%) and filtered onto a $0.8 \mu \mathrm{m}$ pore size Nuclepore membrane filter, washed with distilled water, fixed with osmium, dehydrated with a graded series of ethanol and critical-point-dried with $\mathrm{CO}_{2}$. Filters were mounted on stubs, sputter-coated with gold and viewed using a scanning electron microscope (S4800, Hitachi, Tokyo, Japan).

\section{DNA extraction, PCR amplification and sequencing}

For molecular analysis, each cell of Planodinium striatum was individually picked up with a fine capillary into a clean chamber and washed several times in serial drops of $0.2 \mu \mathrm{m}$ filtered and sterilized seawater. Finally, 3-4 cells were deposited in a $0.2 \mathrm{ml}$ Eppendorf tube filled with several drops of absolute ethanol. The sample was kept at room temperature and in darkness until the molecular analysis was performed. Prior to DNA extraction, the $0.2 \mathrm{ml}$ Eppendorf tubes were centrifuged for $10 \mathrm{~min}$ at $14462 \times \mathrm{g}$ in a centrifuge (MX-201, TOMY, Tokyo, Japan). Ethanol was then evaporated in a vacuum desiccator. Cells were resuspended in $50 \mu \mathrm{L}$ of guanidinecontaining extraction buffer (GITC buffer). After thermal shocks (preserved in $-80{ }^{\circ} \mathrm{C}$ overnight and heated at $70{ }^{\circ} \mathrm{C}$ for $60 \mathrm{~min}$ ), $100 \mu \mathrm{L}$ of isopropanol was added to precipitate the DNA following the protocol described in Nakamura et al. (2015). The precipitated DNA was rinsed with $70 \%$ ethanol and stored in $20 \mu \mathrm{L}$ of TrisEDTA buffer. To amplify SSU rRNA gene fragments, the primers EukA1 and EukB2 (Medlin et al. 1988) were used in a reaction with KAPA3G Plant DNA Polymerase (Kapa Biosystems, U.S.A.). The following thermocycler program was performed: initial denaturation at $95^{\circ} \mathrm{C}$ for $10 \mathrm{~min} ; 45$ cycles of denaturation at $95^{\circ} \mathrm{C}$ for $20 \mathrm{~s}$, annealing at $52{ }^{\circ} \mathrm{C}$ for $15 \mathrm{~s}$, and extension at $72{ }^{\circ} \mathrm{C}$ for $40 \mathrm{~s}$; then final extension at $72{ }^{\circ} \mathrm{C}$ for $7 \mathrm{~min}$. The amplified PCR products were purified with AMPure XP Kit (Beckman Coulter, U.S.A.). Sequencing reactions were conducted using the ABI PRISM BigDye Terminator Cycle Sequencing Kit (Applied Biosystems, Foster City, U.S.A.) and a DNA autosequencer, ABI PRISM 3130xl Genetic Analyzer (ABI, Foster City, U.S.A.). The newly generated consensus sequences were deposited in DDBJ/EMBL/GenBank under accession numbers LC507455 -LC507456.

\section{Phylogenetic analyses}

The alignment used the same sequences and outgroup in the SSU rRNA gene phylogeny by Yamaguchi et al. (2018). We added the two identical sequences of Planodinium striatum obtained from two different samples collected in the beach of Wimereux on 21 and 23 June 2012, two environmental sequences (accession num- 
bers KJ761640, KJ761122) belonging to the Podolampadaceae, the sequence of Plagiodinium ballux (LC054938) and another sequence identified as Plagiodinium belizeanum LC054937 after Yamada et al. (2018). We kept the two sequences of Cabra matta (LC3339367 ) in the alignment despite they were anomalously long (1858 and 1856 base pairs). This is due to numerous insertions (at the positions 180-210, 250-290, and others) that were missing in other dinoflagellate sequences. Sequence alignments were accomplished by ClustalW (Larkin et al. 2007). The general time-reversible model with gamma-distributed rate variation and a proportion of invariable sites $(\mathrm{GTR}+\mathrm{G}+\mathrm{I})$ was selected, and the phylogenetic tree was constructed by Maximum Likelihood method with the default settings in MEGA7 software (Kumar et al. 2016). Bootstrap values were obtained after 1000 replications. The sequence of apicomplexan $\mathrm{Ne}$ ospora caninum (L24380) was used as outgroup as in Yamaguchi et al. (2018).

\section{RESULTS}

The observations of cells of Planodinium striatum were scarce and they were never abundant as usually occur with heterotrophic species. The cells were active swimmers that makes difficult the detection from live samples or they may be mistaken for Sabulodinium undulatum. We observed up to ten cells per day during several days in June 2012 associated with a proliferation of benthic diatoms and photosynthetic dinoflagellates such as Togula spp., Amphidinium spp., Polykrikos lebouriae, among others. Cells of $P$. striatum were colorless with a food vacuole of brown coloration in the lower half of the hypotheca (Fig. 1A-M), and often a large pusule in the upper half of the hypotheca (Fig. 1A-B). The cells were laterally compressed with an oval shape. Dimensions were 28-35 $\mu \mathrm{m}$ long, 23-26 $\mu \mathrm{m}$ depth (dorsoventral length) and $11-15 \mu \mathrm{m}$ wide. The cingulum was horizontal and the epitheca was much smaller and narrower than the hypotheca (Fig. 1A-M). The surface of the hypotheca showed longitudinal ridges (Fig. 1L-M). Most of the collected cells were used for molecular analysis. Only two cells were observed by SEM, but the epitheca of the cells showed attached debris and apparently mucous (Fig. 1N) or were covered by trichocysts (Fig. 1O) that rendered the observations. There was an elongated and slightly sigmoidal plate, the first postcingular plate 1"', adjacent to the left side of the sulcus, while a large rectangular plate, the second postcingular plate 2 ,", occupied most of the left lateral hypotheca (Fig. 1N). This 1 "' plate and other narrow plate (5'”) adjacent to the right side of the sulcus were missing in the original description as probably the sutures were mistaken for longitudinal ridges. The hypothecal plates showed large pores arranged in longitudinal rows (Fig. 1O). Each pore was surrounded by 5-8 small pores. Trichocysts emerged from the large pores. All these characteristics fit the original description confirming that our isolates corresponded to Planodinium striatum.

The two SSU rRNA gene sequences of Planodinium striatum isolated from two samples collected on 21 and 23 June 2012 were identical for 1739 base pairs (bp) (LC507455-6). The sequences of $P$. striatum showed a percentage of similarity of $96 \%$ when compared to the partial sequence of Podolampas elegans (accession number FJ888596, for only 1227 bp). The comparison with full SSU rRNA gene sequences ( $>1700 \mathrm{bp}$ ) showed percentages of similarities of $93 \%$ with those of Plagiodinium belizeanum (KX008973) and Roscoffia capitata (AF521101). In the SSU rRNA gene molecular phylogeny, the sequences of Planodinium striatum clustered with Plagiodinium belizeanum (KX008973) as a sister group of P. ballux (LC054938) and a sequence identified as P. belizeanum (LC054937) (Fig. 2). The sequences of Podolampas spp., Blepharocysta sp. and Roscoffia capitata and two environmental sequences (KJ761122, KJ761640) formed the high supported clade of the Podolampadaceae that was distantly related to the sequences of $P$. striatum and Plagiodinium spp. The anomalous sequences of Cabra matta (LC333936-7) clustered in a basal position of the dinokaryote core (Fig. 2).

\section{DISCUSSION}

The pelagic thecate dinoflagellates are usually globular, with a well-defined equatorial cingulum constituted of horizontally elongated plates with depression harboring the transversal flagellum, and an apex with a conspicuous apical pore plate. Using the cingulum and the apical pore plate as landmarks, we can establish the tabulation of the epitheca after considering the plates above the cingulum as the precingular series, and the plates surrounding the apical pore as the apical series. However, these reference points are missing in numerous sand-dwelling dinoflagellates. The cingulum is usually very anterior that resulted in a small epitheca, and it is difficult to discern the tiny epithecal plates which morphologies are also altered due to the cell flattening. The uncertainties in the assignment of the epithecal plates increase when the 

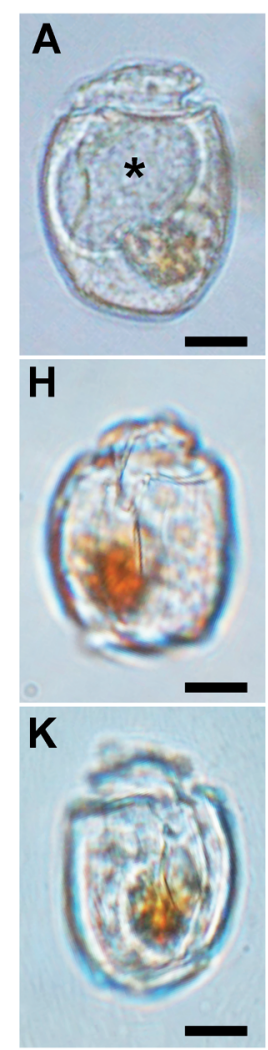
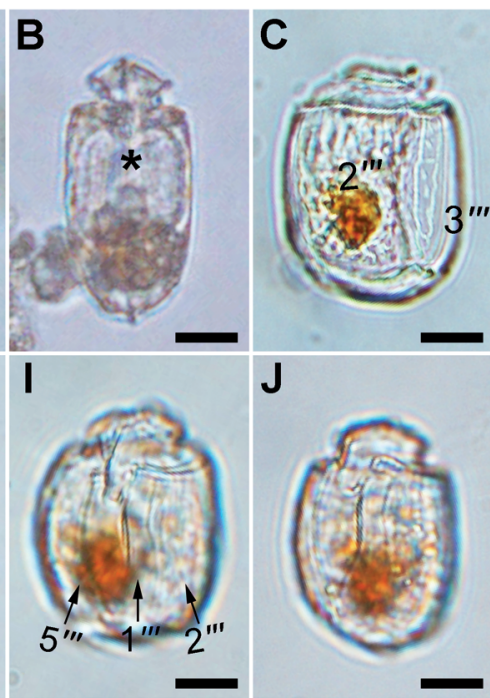

$\mathbf{L}$

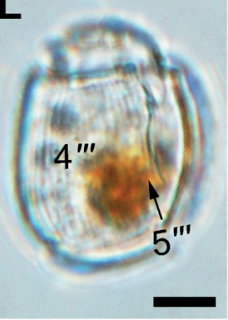

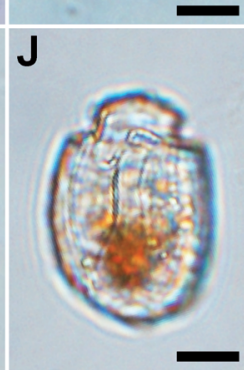

M

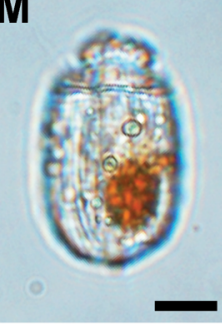

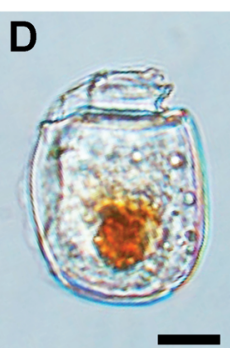
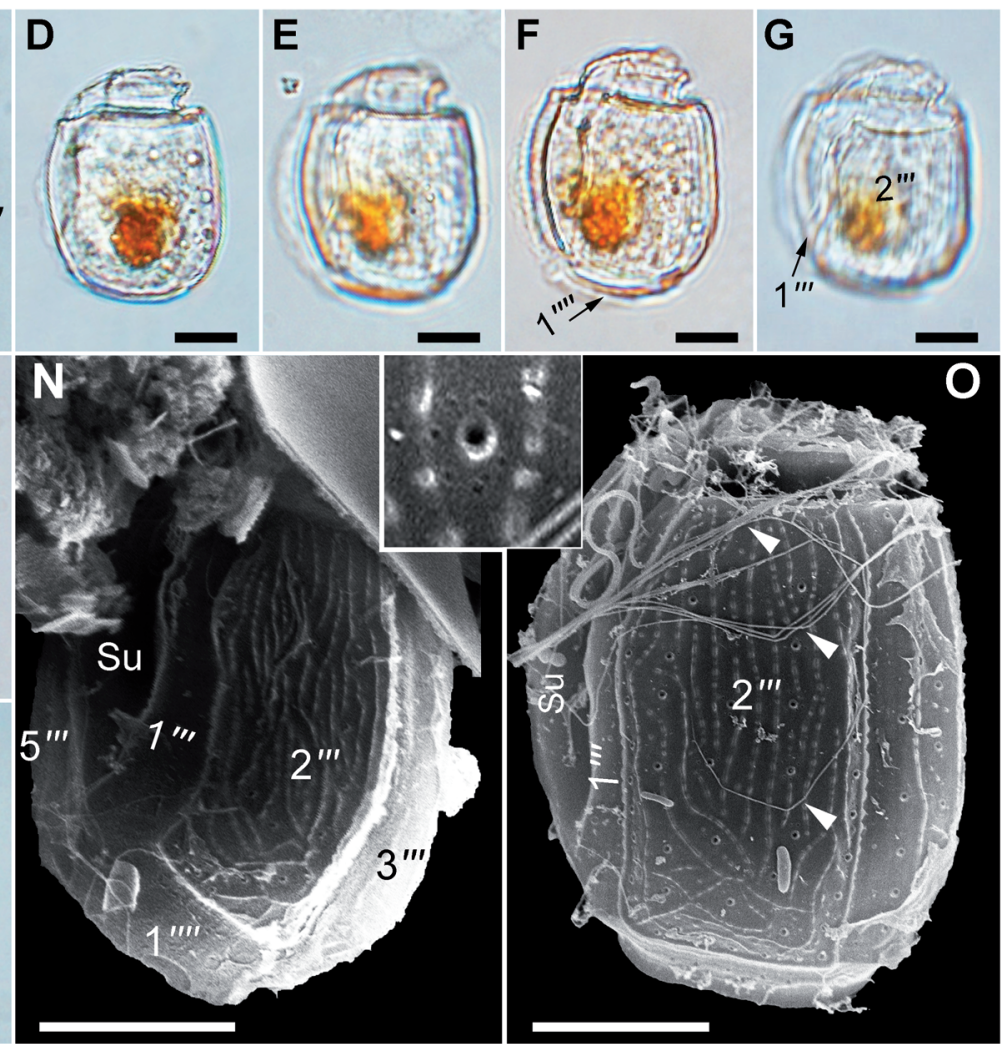

Fig. 1. Light (A-M) and scanning electron microscopy (N-O) images of Planodinium striatum isolated in June 2012 at Wimereux, France. (A-B) A cell in left lateral and dorsal views. Asterisk (*) indicates the pusule. (C-M) Different views of another cell. The arrows indicate hypothecal plates. (N) Cell in ventro-left lateral view. (O) Another cell in left lateral view. The arrowheads indicate the trichocysts. The inset shows a large pore surrounded by several small pores. Scale bar $=10 \mu \mathrm{m}$.

Fig. 2. The phylogenetic position of Planodinium striatum based on Maximum Likelihood analysis inferred from SSU rRNA gene sequences. The new sequences are indicated in bold face. Each species name is followed by an accession number. The bootstrap values $(>70)$ are indicated at each node. Scale bar denotes 0.05 substitutions per site.

cingulum, as a latitudinal series of depressed plates, is apparently missing or incomplete. Then, it is difficult to interpret whether a plate belongs to the cingular, precingular, intercalary and apical series. Successive re-interpretations of the tabulation of the epitheca often occurred in sand-dwelling dinoflagellates such as Cabra (Murray and Patterson 2004, Selina et al. 2015, Yamaguchi et al. 2018). In addition, the criterion of the consideration of the depressed plates as the cingular plate series is variable. For example, the typical pelagic podolampadaceans (Podolampas, Blepharocysta) do not possess a cingulum with depressed plates, but they are considered to have three cingular plates in the position where the transversal flagellum encircles the cell (Carbonell-Moore 2004). The close phylogenetic relationship between the sand-dwelling Roscoffia with the typical depressed cingular plates and the pelagic podolampadaceans (Fig. 2) evidences that the presence of depressed or non-depressed cingular plates is not a diagnostic character at a suprageneric rank. An affinity of the genus Cabra, described with an incomplete cingulum, and the podolampadaceans has been suggested since the original description (Murray and Patterson 2004). Yamaguchi et al. (2018) showed that the SSU rRNA gene sequences of Cabra clustered within the Podolampadaceae. We have built phylogenetic trees with the same taxonomic sampling in Yamaguchi et al. (2018), but we did not find the same topology (Fig. 2). The alignment of the sequences of Cabra (accession numbers LC333936-7) was difficult due to numerous insertions. Yamaguchi et al. (2018) reported Plagiodinium belizeanum as a basal lineage in the clade of the 


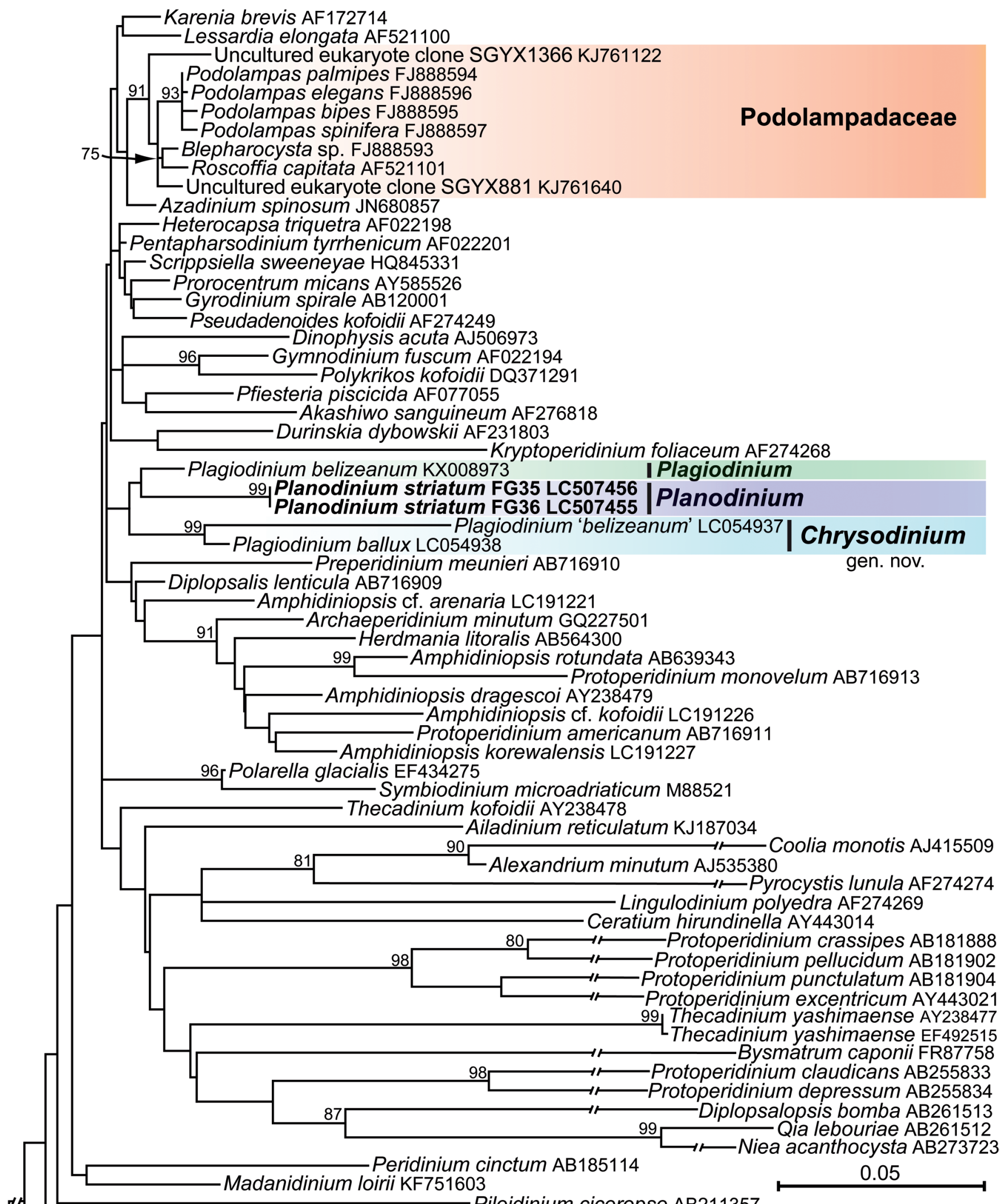

Karenia brevis AF172714

Lessardia elongata AF521100

Uncultured eukaryote clone SGYX1366 KJ761122

Podompas elegans FJ888596

- Podolampas bipes FJ888595

Blepharocysta sp. FJ888593

Roscoffia capitata AF521101

- Uncultured eukaryote clone SGYX881 KJ761640

Azadinium spinosum JN680857

- Heterocapsa triquetra AF022198

entapharsodinium tyrrhenicum AF022201

- Scrippsiella sweeneyae HQ845331

Gyrodinium spirale AB120001

Dinophysis acuta AJ506973

Polykrikos kofoidii DQ371291

Akashiwo sanguineum AF276818

Durinskia dybowskii AF231803

Preperidinium meunieri AB716910

gen. nov.

-Amphidiniopsis cf. arenaria LC191221

Archaeperidinium minutum GQ227501

99 Amphidiniopsis rotunda

Protoperidinium monovelum AB716913

Amis dragescol AY238479

- Amphidiniopsis cf. kofoidii LC191226

Amphidiniopsis korewalensis LC191227

Lingulodinium polyedra AF274269

Ceratium hirundinella AY443014

4

Madanidinium loirii KF751603

Pileidinium ciceropse AB2
99, Cabra matta LC 333936

Cabra matta LC333937

? Podolampadaceae

Neospora caninum L24380 
Podolampadaceae, while previous molecular studies did not show a relationship with podolampadaceans such as Roscoffia (Wakeman et al. 2018, Yamada et al. 2018). The SSU rRNA gene sequences of $P$. striatum show a relative high percentage of similarity ( $\sim 93 \%)$ with Roscoffia and Plagiodinium, and even higher (96\%) when compared to the partial sequences of Podolampas, but the phylogenetic closeness between the Podolampadaceae and Planodinium was not proven by SSU rRNA gene analysis using the taxonomic sampling by Yamaguchi et al. (2018) (Fig. 2). However, we observed an affinity using other taxonomic samplings. This suggests that Planodinium and Plagiodinium share a recent common ancestor with the Podolampadaceae, although the resolution of the rRNA gene markers is insufficient to provide statistical support. The clade of the Podolampadaceae (Podolampas, Blepharocysta, Roscoffia), also including Cabra, contain species with three cingular plates, while Planodinium striatum and Plagiodinium spp. possess five or more cingular plates. Discussions of the interpretation of the tabulation of the genera Plagiodinium and Cabra, and their relationship with the Podolampadaceae are largely reported in recent literature (Wakeman et al. 2018, Yamada et al. 2018, Yamaguchi et al. 2018).

Planodinium and its allied genera Plagiodinium share the same tabulation of the hypotheca than the podolampadaceans (5 "' 1 ,'”) (Fig. 3A-B, D-E). That hypothecal plate arrangement is also present in other sand-dwelling genera such as Madanidinium, Pileidinium or Sabulodinium that do not show any phylogenetic relationship to the podolampadaceans or any other dinoflagellate in the SSU rRNA gene phylogenies (Fig. 2, Yamada et al. 2018, Yamaguchi et al. 2018). Our results support a close phylogenetic relationship between Planodinium and Plagiodinium that always cluster together in molecular phylogenies using different taxonomic samplings, although without robust statistical support (Fig. 2).

The species of Plagiodinium are photosynthetic with a short sulcus, while Planodinium is heterotrophic and the sulcus is long. It should be noted that the prey, tentative amphidinioid dinoflagellates, is ingested through the sulcus. The plate arrangement of the species of Planodinium and Plagiodinium are subjected to an unstable interpretation of the epithecal tabulation. In addition, Planodinium striatum is a heterotrophic species, and the available material for detailed morphological studies is more limited that in a photosynthetic and cultivable genus such as Plagiodinium. Planodinium possesses a relatively well-defined cingulum, but there is no evidence of the apical pore plate. We have distinct situations in the two described species of Plagiodinium, with especial difficulties for $P$. ballux where the cingulum is considered incomplete and the epitheca is very small, being easily overlooked as a Prorocentrum cell during routine light microscopy observations (Yamada et al. 2018). An incomplete cingulum means that depressed plates do not completely encircled the cell at the cingulum level. Then, the interpretation could be that the cingular plates really do not completely encircle the cell and there is an intrusion of the precingular plates at the cingulum level or, alternatively, that the cingulum also contains plates that are not depressed. If we admit non-depressed plates as a part of the cingulum of the typical Podolampadaceae (Podolampas, Blepharocysta), we have to be opened to the same interpretation in Plagiodinium. On the other hand, an absence of cingular plates has been reported in other sand-dwelling dinoflagellates such as Adenoides where there is no depressed plate at the cingulum level (Gómez et al. 2015).

Yamada et al. (2018) described a second species Plagiodinium, P. ballux that showed important genetical and morphological differences when compared to the type species, $P$. belizeanum. The SSU rRNA gene sequence of $P$. ballux (LC054938) showed a percentage of similarity of $95.18 \%$ and $96.37 \%$ with respect to the sequences identified as Plagiodinium belizeanum from Mageshima Island (LC054937) and P. belizeanum from Okinawa Island (KX008973), respectively. This is a too low percentage of similarity for two dinoflagellate species placed under the same genus. In addition, these two SSU rRNA gene sequences identified as $P$. belizeanum (KX008973, LC054937) showed a percentage of similarity of $95.24 \%$ that evidence that the sequences do not belong to the same species, and very likely to distinct genera. Yamada et al. $(2018$, p. 8) reported: "The two registered sequences of $P$. belizeanum were found to differ more than one might reasonably expect for one species. The morphology of the strain linked with the registered sequence KX008973 (Wakeman et al. 2018) was found to be morphologically identical to the original description of $P$. belizeanum". The strain of $P$. belizeanum from Mageshima Island (LC054937) very likely correspond to an undescribed species, but there is no information on its morphology (Yamada et al. 2015, 2018). The isolate of $P$. belizeanum from Okinawa KX008973 corresponded to the morphology of the type species (Faust and Balech 1993, Wakeman et al. 2018). The low percentage of similarity $(96.37 \%)$ be- 
tween $P$. belizeanum from Okinawa and $P$. ballux is also accompanied by important morphological differences that do not support the placement under the same genus (Fig. 3D-I, Table 1). Yamada et al. (2018, p. 5) reported: "The main difference between $P$. belizeanum and $P$. ballux lies with the number of sulcal plates and lack of complete cingulum in the latter. Another difference is that in $P$. belizeanum the presence of a distinct apical pore was demonstrated (Wakeman et al. 2018), while in P. ballux, the pore identified as apical pore is rather obscure".

Wakeman et al. (2018) proposed the plate formula Po 1' 5" 5(6)c 5'" 1 "', for Plagiodinium belizeanum with other three alternative interpretations of the epithecal tabulation as Po 3' 3", Po x 0'5"' and Po x 5'0". The interpretation of the thecal plate arrangement of $P$. belizeanum is relatively easy because the cingulum is complete and contains depressed thecal plates. In contrast, the interpretation of the plate formula of $P$. ballux is controversial, especially the assignation of the plates located at the cingulum level that were labelled as 4 " and 5 " in the original description (Yamada et al. 2018). Taking into account the phylogenetic relationship between Plagiodinium and the Podolampadaceae as shown in Yamaguchi et al. (2018), we have to admit non-depressed plates as a part of the cingulum as occurred in the typical members of the Podolampadaceae (Carbonell-Moore 2004). We can interpret the plates 4" and 5 " in the original description of $P$. ballux as cingular plates. Then, the modified plate formula of P. ballux (Po 3 ' 1 " 7c 2s 5 "' 1 '”') differed from that of $P$. belizeanum [Po 1'5" 5(6)c 4s 5"' 1 '”']. In that case, the members of the Podolompadaceae (with Roscoffia and tentatively Cabra) are characterized by three cingular plates, while the members of the clade of Planodinium striatum and Plagiodinium spp. possess five to eight cingular plates. The two species of Plagiodinium are characterized by a low number $(\leq 6)$ of epithecal plates (Fig. 3F, I), while Planodinium shows more epithecal plates, but very tiny precingular plates in the dorsal epitheca (Fig. 3C).

In the molecular phylogeny including the sequences of Planodinium, the placement of Plagiodinium ballux in the genus Plagiodinium is unsupported as the type species, $P$. belizeanum, is closer to Planodinium striatum (Fig. 2). The sequence of $P$. ballux clusters with an undocumented sequence identified as $P$. belizeanum that very likely correspond to a second species of the genus of P. ballux (Fig. 2). This suite of morphological and molecular differences leads to the conclusion that the species $P$. ballux should be placed into another genus.

\section{Taxonomic description}

Chrysodinium F. Gómez, Y. Nakamura \& Artigas, gen. nov.

LSID urn:1sid:zoobank.org:act:9637DE42-84A34A7A-B6BF-665619CB30B8

\section{Diagnosis}

Laterally compressed thecate dinoflagellates with a very small epitheca. The cingulum was hardly recognizable being difficult to discern the epitheca clearly. A very short sulcus could be seen near the apex of the cell. The hypotheca consisted of six plates: five postcingulars and one antapical plate ( 5 "', 1 '”'). The 1 "” plate is located directly below the sulcus. The 2 "' and 4 "' plates were the largest of all the plates and placed on the left and right sides, respectively. There is a single antapical plate ( 1 '”') that is located in the antapex. The sulcus contains an anterior and posterior plate. The interpretation of the tabulation of the epitheca is difficult. There is no a complete latitudinal series of depressed plates encircling the cell. There are five depressed plates that can be unequivocally attributed to the cingular series, and other two non-depressed plates near the sulcus in the right lateral side that are here also assigned to the cingular series. There is an inconspicuous apical pore plate surrounded by three apical plates, and one precingular plate in the left lateral side. The plate formula is interpreted as Po 3' 1" 7c 2s 5"' 1'”.'. All the known species are photosynthetic and living in marine benthic habitats.

Type species: Chrysodinium ballux (N. Yamada, Dawut, R. Terada \& Horiguchi) F. Gómez, Y. Nakamura \& Artigas comb. nov. (designated here).

Icotype: Fig. $3 \mathrm{H}$

Etymology: Chryso: From Ancient Greek $\chi \rho v \sigma o ́ s$ (khrusós, the color gold, golden, golden yellow). The epithet of the type species refers to the golden coloration. The suffix '-dinium', meaning 'vortex' is commonly applied to dinoflagellates. The gender is neuter. Basionym: Plagiodinium ballux N. Yamada, Dawut, R. Terada \& Horiguchi (2018, Phycological Research 67, p. 8-9, figs. 1-4)

Yamada et al. (2018) designed the SEM stub SAP 115372 as holotype, but no figure is assigned to the holotype. The figures 1-4 correspond to distinct specimens. We design the specimen of the figure $2 b$ in Yamada et al. (2018) as type (Article 8.1 of International Code of Nomenclature, I.C.N.).

Other species belonging to Chrysodinium: Plagiodinium belizeanum sensu Yamada et al. 2018 (non P. belizeanum sensu Wakeman et al. 2018). 

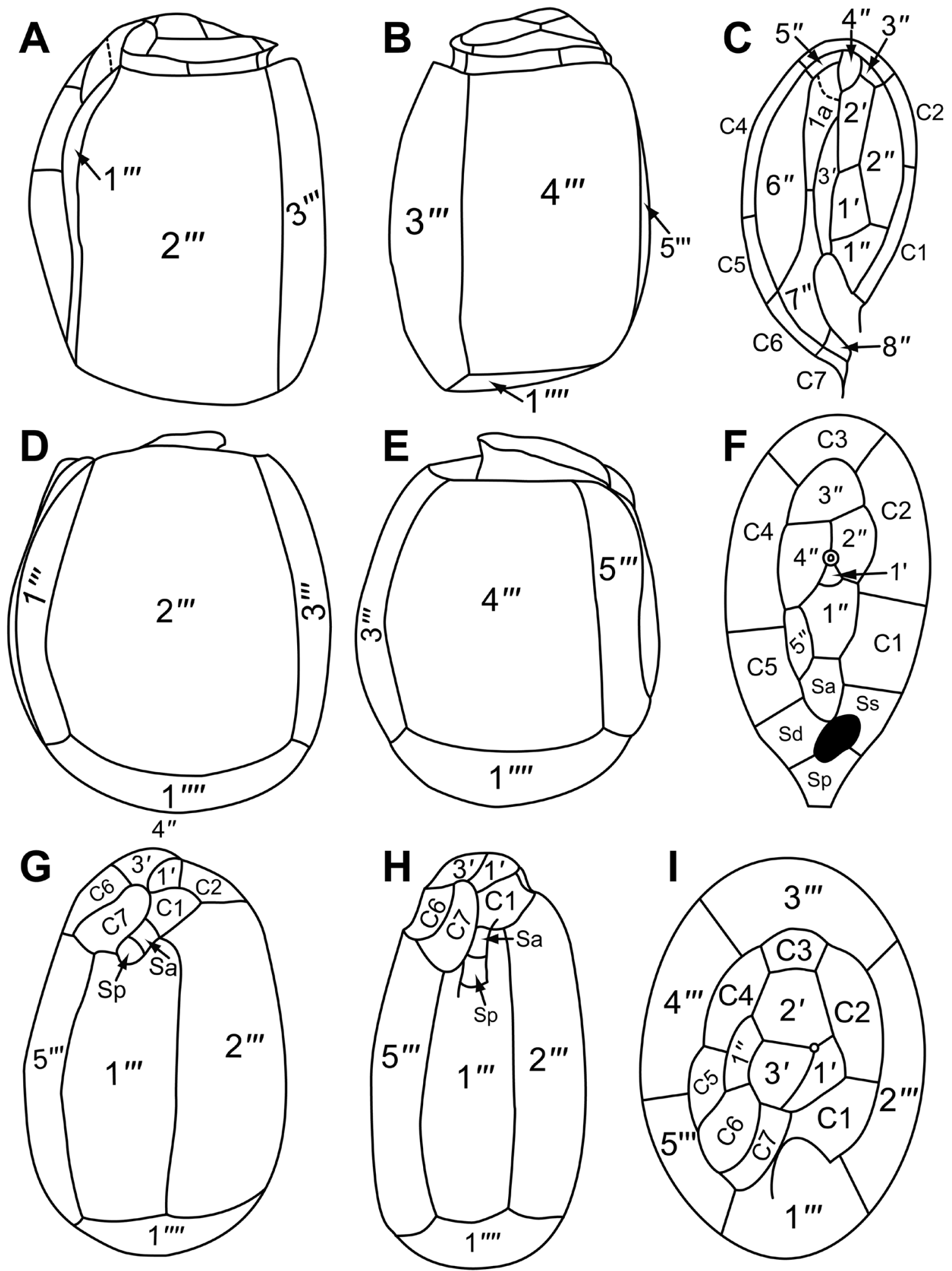

Fig. 3. Line drawings of the plate arrangement of Planodinium striatum (A-C), Plagiodinium belizeanum (D-F) and Chrysodinium ballux gen. nov. \& comb. nov. (=Plagiodinium ballux) (G-I). Left lateral (A), right lateral (B), apical (C) views of Planodinium striatum redrawn from Hoppenrath et al. (2014). Left lateral (D), right lateral (E) and apical (F) views of Plagiodinium belizeanum redrawn from Wakeman et al. (2018). Left lateral (G), ventral (H) and apical (I) views of Chrysodinium ballux gen. \& comb. nov. redrawn from Yamada et al. (2018) with a re-interpreted tabulation. 
Table 1. Comparative morphological characteristics of Planodinium striatum, Plagiodinium belizeanum and Chrysodinium ballux gen. nov. \& comb. nov. (=Plagiodinium ballux) based on Hoppenrath et al. (2014), Wakeman et al. (2018), Yamada et al. (2018) and this study.

\begin{tabular}{|c|c|c|c|}
\hline & Planodinium striatum & Plagiodinium belizeanum & $\begin{array}{l}\text { Chrysodinium ballux (=Plagiodinium } \\
\text { ballux) }\end{array}$ \\
\hline Cell dimensions (in $\mu \mathrm{m}$ ) & 28-35 long, 23-26 depth & 13-34 long, 6-18 depth & 15-23 long, 10-17 depth \\
\hline Cell shape & almost rectangular & oval to oblong & oval \\
\hline Cell compression & high & moderate & low \\
\hline Epitheca & conspicuous & small cap-like with dorsal tapering & hardly visible \\
\hline Cingulum & horizontal, with narrow depressed plates & small with wide plates & $\begin{array}{l}\text { inconspicuous, with depressed and non- } \\
\text { depressed plates }\end{array}$ \\
\hline $\begin{array}{l}\text { Number of cingular } \\
\text { plates }\end{array}$ & 6 or 7 & 5 or 6 & 5 (depressed) +2 (non-depressed) \\
\hline Sulcus & long & short with 4 plates & $\begin{array}{l}\text { very short with } 2 \text { plates (anterior and } \\
\text { posterior) }\end{array}$ \\
\hline Apical pore plate & unreported & ring-like & $\begin{array}{l}\text { inconspicuous } \\
\text { simple pore }\end{array}$ \\
\hline Plate formula & Po? 3' 1a 8"7?c 5", 1 ",” & Po 1 ' 5 "' $5(6)$ c 5 "' 1 ,"’' & Po 3'1”7c $5, ", 1, "$, \\
\hline First postcingular plate & narrow, adjacent to left sulcus & narrow, adjacent to left sulcus & wide, below the sulcus \\
\hline Surface ornamentation & $\begin{array}{l}\text { two } \\
\text { different size pore classes, longitudinal } \\
\text { ridges }\end{array}$ & $\begin{array}{l}\text { two } \\
\text { different size pore classes, intercalary } \\
\text { bands with striation }\end{array}$ & small pores near the sutures \\
\hline Chloroplast & heterotroph & radiating from the center with lobes & reticulate \\
\hline Pyrenoid & - & multistalked & multistalked, ring-shaped \\
\hline Pusule & prominent & non-observed & reported \\
\hline
\end{tabular}

Acknowledgments. F.G. was supported by an invited lecturer grant from Université Littoral Côte d'Opale in June 2012. The molecular analyses were supported by JSPS KAKENHI (grant number JP17J03204 to Y. N.)

\section{REFERENCES}

Baillie K. D. (1971) A taxonomic and ecological study of intertidal sand-dwelling dinoflagellates of the north eastern Pacific Ocean M.S. Thesis, University of British Columbia, Vancouver

Balech E. (1956) Étude des Dinoflagellés du sable de Roscoff. Rev. Algol., n. s. 2: 29-52

Carbonell-Moore M. C. (2004) On the taxonomical position of Lessardia Saldarriaga et Taylor within the family Podolampadaceae Lindemann (Dinophyceae). Phycol. Res. 52: 340-345

Carbonell-Moore M. C. (2017) The rediscovery of Archaeosphaerodiniopsis Rampi (Dinophyceae). Eur. J. Phycol. 52: 57-63

Faust M. A., Balech E. (1993) A further SEM study of marine benthic dinoflagellates from a mangrove island, Twin Cays, Belize, including Plagiodinium belizeanum gen. et sp. nov. J. Phycol. 29: $826-832$

Gómez F., Moreira D., López-García P. (2010) Molecular phylogeny of the dinoflagellates Podolampas and Blepharocysta (Peridiniales, Dinophyceae). Phycologia 49: 212-220
Gómez F., López-García P., Moreira D. (2011) Molecular Phylogeny of the sand-dwelling dinoflagellates Amphidiniopsis hirsuta and $A$. swedmarkii (Peridiniales, Dinophyceae). Acta Protozool. 50: $255-262$

Gómez F., Artigas L. F. (2014) High diversity of dinoflagellates in the intertidal sandy sediments of Wimereux (north-east English Channel, France). J. Mar. Biol. Ass. U.K. 94: 443-457

Gómez F., Onuma R., Artigas L. F., Horiguchi T. (2015) A new definition of Adenoides eludens, an unusual marine sand-dwelling dinoflagellate without cingulum, and Pseudadenoides kofoidii gen. \& comb. nov. for the species formerly known as Adenoides eludens. Eur. J. Phycol. 50: 125-138

Horiguchi T., Kubo F. (1997) Roscoffia minor sp. nov. (Peridiniales, Dinophyceae); a new, sand-dwelling, armored dinoflagellate from Hokkaido, Japan. Phycol. Res. 45: 65-69

Hoppenrath M., Elbrächter M. (1998) Roscoffia capitata (Dinophyceae) refound: notes on morphology and biology. Phycologia 37: 450-457

Hoppenrath M., Murray S. A., Chomérat N., Horiguchi T. (2014) Marine benthic dinoflagellates - unravelling their worldwide biodiversity. Kleine Senckenberg-Reihe Vol. 54. V. Mosbrugger \& E. Schweizerbartsche Verlagsbuchhandlung, Frankfurt am Main \& Stuttgar

Larkin M. A., Blackshields G., Brown N. P., Chenna R., McGettigan P. A., McWilliam H., Valentin, F., Wallace I. M., Wilm A., 
Lopez R., Thompson J. D., Gibson T. J., Higgins D. G. (2007) Clustal W and Clustal X version 2.0. Bioinformatics 23: $2947-$ 2948

Medlin L., Elwood H., Stickel S., Sogin M. (1988) The characterization of enzymatically amplified eukaryotic 16S-like rRNA coding regions. Gene 71: 491-499

Murray S., Patterson D. J. (2004) Cabra matta, gen. nov., sp. nov., a new benthic, heterotrophic dinoflagellate. Eur. J. Phycol. 39: 229-234

Nakamura Y., Imai I., Yamaguchi A., Tuji A., Not F., Suzuki N. (2015) Molecular phylogeny of the widely distributed marine protists, Phaeodaria (Rhizaria, Cercozoa). Protist 166: 363-373

Saldarriaga J. F., Leander B. S., Taylor F. J. R., Keeling P. J. (2003) Lessardia elongata gen. et sp. nov. (Dinoflagellata, Peridinales), Podolampaceae and the taxonomic position of the genus Roscoffia. J. Phycol. 39: 368-378

Saunders R. D., Dodge J. D. (1984) An SEM study and taxonomic revision of some armoured sand-dwelling marine dinoflagellates. Protistologica 20: 271-283

Selina M., Chomérat N., Hoppenrath M. 2015. Morphology and spatial distribution of Cabra species (Dinophyceae, Peridini- ales) from Peter the Great Bay (northwestern Sea of Japan), including the description of C. levis sp. nov. Eur. J. Phycol. 50: 80-91

Wakeman K. C., Hoppenrath M., Yamaguchi A., Gavelis G. S., Leander B. S., Nozaki, H. (2018) Ultrastructure of the marine benthic dinoflagellate Plagiodinium belizeanum (Dinophyceae) from the Southeast Pacific island of Okinawa, Japan. Phycologia 57: 209-222

Yamada N., Tanaka A., Horiguchi T. (2015) Pigment compositions are linked to the habitat types in dinoflagellates. J. Plant Res. 128: $923-932$

Yamada N., Dawut M., Terada R., Horiguchi T. (2018) Plagiodinium ballux sp. nov. (Dinophyceae), a deep (36 m) sand dwelling dinoflagellate from subtropical Japan. Phycol. Res. 67: 12-20

Yamaguchi A., Wakeman K. C., Hoppenrath M., Horiguchi T., Kawai H. (2018) Molecular phylogeny of the benthic dinoflagellate Cabra matta (Dinophyceae) from Okinawa, Japan. Phycologia 57: 630-640

Received on $30^{\text {th }}$ August, 2019; revised on $1^{\text {st }}$ November, 2019; accepted on $4^{\text {th }}$ November, 2019 